Article

\title{
New Homoisoflavanes, a New Alkaloid and Spirostane Steroids from the Roots of Herreria montevidensis Klotzsch ex Griseb. (Herreriaceae) ${ }^{\dagger}$
}

\author{
María Dutra-Behrens ${ }^{1}$ and Guillermo Schmeda-Hirschmann ${ }^{2, *}$ \\ 1 Departamento de Produtos Naturais, Instituto de Tecnologia em Fármacos da Fundação Oswaldo \\ Cruz-Farmanguinhos/Fiocruz, Rua Sizenando Nabuco 100, 21041-250 Rio de Janeiro, Brazil; \\ behrens@fiocruz.br or mbehrens@far.fiocruz.br \\ 2 Instituto de Química de Recursos Naturales, Universidad de Talca, Casilla 747, 3460000 Talca, Chile \\ * Correspondence: schmeda@utalca.cl; Tel.: +56-71-220-0288 \\ † In memory of Professor Gerhard Habermehl, Chemisches Institut der Tierärztlichen Hochschule Hannover, \\ Germany, and Prof. Jasmin Jakupovic, Institut für Organische Chemie, TU Berlin, Berlin, Germany.
}

Academic Editor: Thomas J. Schmidt

Received: 15 September 2016; Accepted: 17 November 2016; Published: 21 November 2016

\begin{abstract}
The roots of the South American vine Herreria montevidensis Klotzsch ex Griseb. (Herreriaceae) are used in traditional medicine by several Amerindian groups of the Paraguayan Chaco. Little is known on the chemistry of the plant, despite its widespread use across the South American Chaco. From the ethyl acetate/methanol 1:1 extract of the roots, four new and one known homoisoflavanoid, two flavan derivatives, a stilbene, a new alkaloid, and three new and four known spirostane steroids were isolated. The corresponding structures were elucidated by spectroscopic and spectrometric means. The homoisoflavonoids of the plant are related to compounds isolated from the Dracaenaceae (formerly Agavaceae) sources of the Chinese crude drug Dragon's Blood. The new alkaloid is a novel skeleton that can be used as a chemical marker of Herreria. The spirostane steroids suggest chemotaxonomic relations with the Liliales. This is the first comprehensive report on the chemistry of a South American Herreria species.
\end{abstract}

Keywords: Herreria montevidensis Klotzsch ex Griseb.; Herreriaceae; homoisoflavanoids; flavans; spirostane steroids; alkaloid

\section{Introduction}

The vine Herreria montevidensis Klotzsch ex Griseb. (family Herreriaceae) is abundant in the Chaco domains of South America. It is used in traditional medicine by many Amerindian groups of the Paraguayan Chaco. The Ayoreo rubbed the stem sap on the knees of children to accelerate growth [1]. Additionally, the plant is also used to treat rheumatism [1]. The Lengua-Maskoy use the mashed roots of $H$. montevidensis as an additive to mate, a traditional drink prepared with cold water [2]. The underground parts, mainly roots, are used either as water maceration or decoction as a diuretic and the stems are collected for craftwork and handicrafts [3].

Species of Herreria and the closely related Smilax are widely used in Brazilian popular medicine as a sudorific and to treat skin diseases, gout, rheumatism and syphilis [4]. The closely related species H. salsaparilha and Smilax spp. are known as "salsaparilla" or "salsaparrilha" and are used for the same purposes by the Paraguayan and Brazilian country-dwellers living in the Chaco and Brazilian Pantanal. Despite this widespread use, little is known on the chemistry of the South American genus Herreria (Herreriaceae). Isolation of gitogenin from the roots of H. stellata was reported [5]. According to 
SciFinder (accessed on 30 August 2016), a 1973 report in a local Brazilian journal informed of the occurrence of steroidal saponins in the roots of H. montevidensis [6], however, these saponins were neither isolated nor identified.

To gain insight into the chemistry of Paraguayan Chaco plants used by Native Americans, the objective of this investigation was the isolation and characterization of the roots constituents of H. montevidensis.

\section{Results and Discussion}

The root extract of Herreria montevidensis Klotzsch ex Griseb. yielded four new (compounds 2-5) and the known homoisoflavane 1, the known flavanes 6 and 7, the stilbene 8, the new alkaloid 9 and seven spirostane steroids 10-16, four of which (compounds 11, 14-16) are described for the first time (Figure 1).
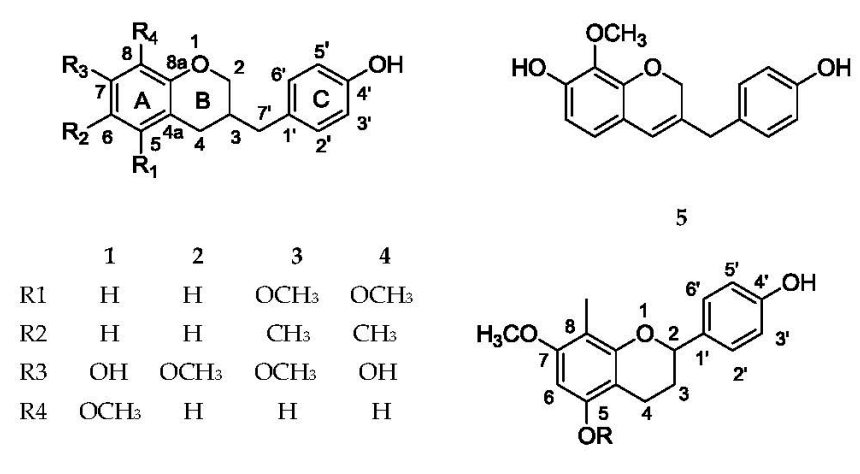

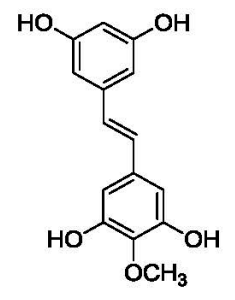

8

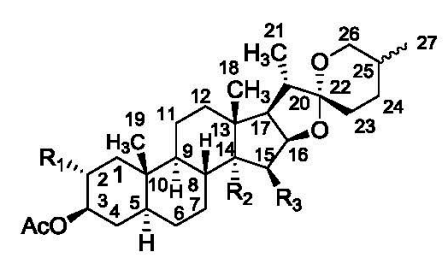

10-15
$6 \mathrm{R}=\mathrm{H} ; \quad \quad \quad \quad \mathrm{R}=\mathrm{CH}_{3}$

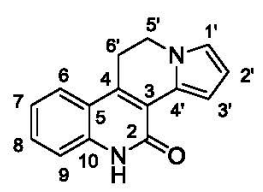

9

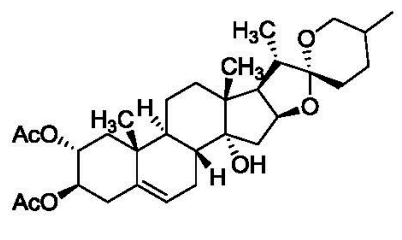

16

$\begin{array}{lllllll} & 10 & 11 & 12 & 13 & 14 & 15 \\ \mathrm{R}_{1} & \text { OAc } & \text { OAc } & \text { OAc } & \text { OAc } & \text { H } & \text { OAc } \\ \mathrm{R}_{2} & \mathrm{H} & \text { OH } & \mathrm{H} & \mathrm{H} & \mathrm{OH} & \mathrm{OH} \\ \mathrm{R}_{3} & \mathrm{H} & \mathrm{H} & \mathrm{OAC} & \mathrm{H} & \mathrm{H} & \mathrm{H} \\ 27-\mathrm{Me} & \alpha & \alpha & \alpha & \beta & \mathrm{B} & \beta\end{array}$

Figure 1. Chemical structures of the compounds 1-16 isolated from Herreria montevidensis roots.

The ${ }^{1} \mathrm{H}-\mathrm{NMR}$ spectra of compounds 1-4 (Table 1) showed in common a fragment composed of a central methine with three attached methylene groups (ring B), a $p$-hydroxyphenyl ring (ring C) and one to three aromatic $\mathrm{H}$ from a second phenyl ring (ring A), suggesting a three ring systems. The chemical shift of the methylene groups required that two of them be in benzylic positions and 
one bear an oxygen function. These structural elements are in agreement with the homoisoflavane skeleton. In all compounds, the B-ring was disubstituted with a hydroxy group in the para-position. The substitution patterns of the A-ring were deduced from the splitting of aromatic signals. The relative placement of the substituents was deduced by comparison with literature and from the NOE difference spectra. The ${ }^{13} \mathrm{C}-\mathrm{NMR}$ data of the compounds 1-4 clearly shows the common structural features with the $t$ at $\delta 69-70$ ppm for C-2, a d at $\delta 34-39$ ppm for C-3 and two $t$ at $\delta 25-30$ and $\delta 37$ ppm for C-4 and C-7', respectively. The ${ }^{13} \mathrm{C}-\mathrm{NMR}$ data of compounds $\mathbf{1}-\mathbf{7}$ is summarized in Table 2.

Table 1. ${ }^{1} \mathrm{H}-\mathrm{NMR}-\mathrm{Spectral}$ Data of Compounds 1-5 (400 MHz, $\mathrm{CDCl}_{3}$, or $\mathrm{CDCl}_{3}+\mathrm{MeOH}-d_{4}$, $\delta$-values in ppm, $J$ values in $\mathrm{Hz}$ ).

\begin{tabular}{|c|c|c|c|c|c|}
\hline Position & $1 \mathrm{CDCl}_{3}+\mathrm{MeOH}-d_{4}$ & 2 & $3 \mathrm{CDCl}_{3}+\mathrm{MeOH}-d_{4}$ & $4 \mathrm{CDCl}_{3}+\mathrm{MeOH}-d_{4}$ & 5 \\
\hline 21 & $4.24 \mathrm{dd}(10.4,1.2)$ & $4.06 \mathrm{dd}(10.4,1.2)$ & $4.09 \mathrm{dd}(10.4,1.2)$ & $4.07 \mathrm{dd}(10.4,1.2)$ & 4.59 brs \\
\hline 22 & $3.83 \mathrm{dd}(10.4,8.8)$ & $3.69 \mathrm{dd}(10.4,8.8)$ & 3.77 dd $(10.4,8.8)$ & 3.73 dd $(10.4,8.8)$ & - \\
\hline 3 & $2.25 \mathrm{~m}$ & $2.15 \mathrm{~m}$ & $2.20 \mathrm{~m}$ & $2.17 \mathrm{~m}$ & - \\
\hline $4_{1}$ & $2.73 \mathrm{dd}(16.0,5.2)$ & $2.62 \mathrm{dd}(16.0,5.2)$ & $2.79 \mathrm{dd}(16.0,5.2)$ & $2.78 \mathrm{dd}(16.0,5.2)$ & 6.04 brs \\
\hline $4_{2}$ & $2.41 \mathrm{dd}(16.0,8.8)$ & $2.33 \mathrm{dd}(16.0,8.0)$ & $2.37 \mathrm{dd}(16.0,8.0)$ & $2.35 \mathrm{dd}(16.0,8.4)$ & \\
\hline 5 & $6.63 \mathrm{~d}(8.4)$ & $6.75 \mathrm{~d}(8.4)$ & - & - & $6.53 \mathrm{~d}(8.0)$ \\
\hline 6 & $6.48 \mathrm{~d}(8.4)$ & $6.28 \mathrm{dd}(8.4,2.5)$ & - & - & $6.44 \mathrm{~d}(8.0)$ \\
\hline 8 & - & $6.21 \mathrm{~d}(2.5)$ & $6.18 \mathrm{~s}$ & $6.13 \mathrm{~s}$ & - \\
\hline $2^{\prime}, 6^{\prime}$ & $7.04 \mathrm{~d}(7.6)$ & $6.95 \mathrm{~d}(8.0)$ & $7.04 \mathrm{~d}(8.0)$ & $7.02 \mathrm{~d}(8.0)$ & $7.01 \mathrm{~d}(8.0)$ \\
\hline $3^{\prime}, 5^{\prime}$ & $6.78 \mathrm{~d}(7.6)$ & $6.70 \mathrm{~d}(8.0)$ & $6.75 \mathrm{~d}(8.0)$ & $6.77 \mathrm{~d}(8.0)$ & $6.73 \mathrm{~d}(8.0)$ \\
\hline $7^{\prime}{ }_{1}$ & $2.58 \mathrm{dd}(13.6,7.6)$ & $2.52 \mathrm{dd}(15.2,7.6)$ & $2.69 \mathrm{dd}(15.2,7.6)$ & $2.61 \mathrm{dd}(13.6,7.2)$ & 3.28 brs \\
\hline $7_{2}^{\prime}$ & $2.52 \mathrm{dd}(13.6,7.2)$ & $2.45 \mathrm{dd}(15.2,7.6)$ & $2.59 \mathrm{dd}(15.2,7.6)$ & $2.56 \mathrm{dd}(13.6,7.2)$ & \\
\hline $\mathrm{Me}$ & - & - & $2.06 \mathrm{~s}$ & $2.08 \mathrm{~s}$ & - \\
\hline $\mathrm{OMe}$ & $3.84 \mathrm{~s}$ & $3.77 \mathrm{~s}$ & $3.66 \mathrm{~s}$ & - & $3.81 \mathrm{~s}$ \\
\hline $\mathrm{OMe}$ & - & - & $3.75 \mathrm{~s}$ & $3.67 \mathrm{~s}$ & - \\
\hline
\end{tabular}

Table 2. ${ }^{13} \mathrm{C}-\mathrm{NMR}$ Spectral Data of Compounds 1-7 (100 MHz, $\mathrm{CDCl}_{3}$ or $\mathrm{CDCl}_{3}+\mathrm{MeOH}-d_{4}$, $\delta$-values in $\mathrm{ppm})$.

\begin{tabular}{|c|c|c|c|c|c|c|c|}
\hline Position & $\begin{array}{l}1 \mathrm{CDCl}_{3}+ \\
\mathrm{MeOH}-d_{4}\end{array}$ & 2 & $\begin{array}{l}3 \mathrm{CDCl}_{3}+ \\
\mathrm{MeOH}-d_{4}\end{array}$ & $\begin{array}{l}4 \mathrm{CDCl}_{3}+ \\
\mathrm{MeOH}-d_{4}\end{array}$ & 5 & 6 & 7 \\
\hline 2 & $70.0 \mathrm{t}$ & $69.9 \mathrm{t}$ & $69.6 \mathrm{t}$ & $69.6 \mathrm{t}$ & $68.0 \mathrm{t}$ & $77.1 \mathrm{~d}$ & $77.0 \mathrm{~d}$ \\
\hline 3 & $34.0 \mathrm{~d}$ & $34.3 \mathrm{~d}$ & $33.9 \mathrm{~d}$ & $33.9 \mathrm{~d}$ & $128.6 \mathrm{~s}$ & $19.4 \mathrm{t}$ & $19.5 \mathrm{t}$ \\
\hline 4 & $30.3 \mathrm{t}$ & $30.2 \mathrm{t}$ & $25.5 \mathrm{t}$ & $25.5 \mathrm{t}$ & $119.6 \mathrm{~d}$ & $29.4 \mathrm{t}$ & $29.5 \mathrm{t}$ \\
\hline $4 \mathrm{a}$ & $114.4 \mathrm{~s}$ & $112.8 \mathrm{~s}$ & $111.4 \mathrm{~s}$ & $110.0 \mathrm{~s}$ & $116.6 \mathrm{~s}$ & $103.9 \mathrm{~s}$ & $106.2 \mathrm{~s}$ \\
\hline 5 & $124.4 \mathrm{~d}$ & $124.4 \mathrm{~d}$ & $157.3 \mathrm{~s} *$ & $157.2 \mathrm{~s}$ & $121.1 \mathrm{~d}$ & $155.7 \mathrm{~s}$ & $155.7 \mathrm{~s}$ \\
\hline 6 & $107.5 \mathrm{~d}$ & $108.1 \mathrm{~d}$ & $107.0 \mathrm{~s}$ & $106.5 \mathrm{~s}$ & $107.6 \mathrm{~d}$ & $90.9 \mathrm{~d}$ & $87.8 \mathrm{~d}$ \\
\hline 7 & $147.5 \mathrm{~s}$ & $150.0 \mathrm{~s}$ & $154.0 \mathrm{~s}$ & $154.3 \mathrm{~s}$ & $149.0 \mathrm{~s}$ & $154.1 \mathrm{~s}$ & $155.0 \mathrm{~s}$ \\
\hline 8 & $134.8 \mathrm{~s}$ & $102.8 \mathrm{~d}$ & $95.3 \mathrm{~d}$ & $98.7 \mathrm{~d}$ & $134.8 \mathrm{~s}$ & $102.6 \mathrm{~s}$ & $103.5 \mathrm{~s}$ \\
\hline $8 a$ & $147.2 \mathrm{~s}$ & $154.8 \mathrm{~s}$ & $157.2 \mathrm{~s} *$ & $152.9 \mathrm{~s}$ & $145.2 \mathrm{~s}$ & $152.9 \mathrm{~s}$ & $155.0 \mathrm{~s}$ \\
\hline $1^{\prime}$ & $130.4 \mathrm{~s}$ & $130.3 \mathrm{~s}$ & $131.6 \mathrm{~s}$ & $130.5 \mathrm{~s}$ & $131.0 \mathrm{~s}$ & $133.5 \mathrm{~s}$ & $134.4 \mathrm{~s}$ \\
\hline $2^{\prime}, 6^{\prime}$ & $129.9 \mathrm{~d}$ & $129.9 \mathrm{~d}$ & $130.1 \mathrm{~d}$ & $129.8 \mathrm{~d}$ & $129.8 \mathrm{~d}$ & $127.1 \mathrm{~d}$ & $127.2 \mathrm{~d}$ \\
\hline $4^{\prime}$ & $154.8 \mathrm{~s}$ & $154.9 \mathrm{~s}$ & $154.3 \mathrm{~s}$ & $154.9 \mathrm{~s}$ & $155.2 \mathrm{~s}$ & $156.0 \mathrm{~s}$ & $156.6 \mathrm{~s}$ \\
\hline $3^{\prime}, 5^{\prime}$ & $115.2 \mathrm{~d}$ & $115.2 \mathrm{~d}$ & $115.2 \mathrm{~d}$ & $115.1 \mathrm{~d}$ & $115.2 \mathrm{~d}$ & $115.1 \mathrm{~d}$ & $115.1 \mathrm{~d}$ \\
\hline $7^{\prime}$ & $36.9 \mathrm{t}$ & $37.0 \mathrm{t}$ & $37.2 \mathrm{t}$ & $37.2 \mathrm{t}$ & $38.8 \mathrm{t}$ & - & - \\
\hline $\mathrm{CH}_{3}$ & - & - & $8.5 \mathrm{q}$ & $8.2 \mathrm{q}$ & - & $7.6 \mathrm{q}$ & $7.8 \mathrm{q}$ \\
\hline $5-\mathrm{OCH}_{3}$ & - & - & $59.9 \mathrm{q}$ & $59.7 \mathrm{q}$ & - & - & $56.0 \mathrm{q}^{* *}$ \\
\hline $7-\mathrm{OCH}_{3}$ & - & $60.7 \mathrm{q}$ & $55.5 \mathrm{q}$ & - & - & $55.3 \mathrm{q}$ & $55.5 \mathrm{q}^{* *}$ \\
\hline $8-\mathrm{OCH}_{3}$ & $60.7 \mathrm{q}$ & - & - & - & $60.8 \mathrm{q}$ & - & - \\
\hline
\end{tabular}

The ${ }^{1} \mathrm{H}-\mathrm{NMR}$ spectrum of compound 1 showed in addition to the $-\mathrm{OCH}_{2}-\mathrm{CH}-\left(\text { benzylic } \mathrm{CH}_{2}\right)_{2}$ sequence (ring B) and the 4-hydroxybenzyl ring (ring C), two aromatic $\mathrm{H}$ at $\delta 6.48$ and $\delta 6.63 \mathrm{ppm}$ $(J=8 \mathrm{~Hz})$ and a methoxy s at $\delta 3.84$ from ring A. The exact placement of the $\mathrm{OCH}_{3}$ was deduced from the HMBC experiments that showed clear correlations between the s peak at 3.84 ppm and the $C$ at $\delta 134.8$, as well as between the H-6 signal at $\delta 6.48$ and the $C$ at $\delta 134.8$. The structure is in agreement with 7-hydroxy-8-methoxy-3-(4-hydroxybenzyl)chroman, previously isolated from the crude drug Dragon's Blood [7]. The compound was also reported from Dracaena cinnabari [8]. 
The closely related compound 2 differs from 1 in the $\mathrm{H}$ number and sequence in the aromatic ring. The ${ }^{1} \mathrm{H}-\mathrm{NMR}$ spectrum of 2 shows three $\mathrm{H}$ signals at $\delta 6.75(\mathrm{~d}, J=8 \mathrm{~Hz}), 6.28(\mathrm{dd}, J=8$ and $2.5 \mathrm{~Hz})$ and $6.21 \mathrm{ppm}(\mathrm{d}, J=2.5 \mathrm{~Hz})$, supporting a 1,2,4 sequence in the aromatic ring as well as a methoxy singlet at $\delta 3.77 \mathrm{ppm}$. The placement of the methoxy group at C-7 follows from the substitution pattern and shielding of H-6 and H-8 as well as from biosynthetic considerations. The molecular formula deduced from the mass spectrum $\left(\mathrm{C}_{17} \mathrm{H}_{18} \mathrm{O}_{3}\right)$ as well as the fragmentation pattern is in agreement with the proposed structure. The compound was thus identified as 7-methoxy-3-(4-hydroxybenzyl)chroman and is reported for the first time.

The ${ }^{1} \mathrm{H}-\mathrm{NMR}$ spectra of compounds 3 and 4 (Table 1 ) showed only one aromatic $\mathrm{H}$ for the A-ring. The substituents were deduced from the typical chemical shifts as a methyl and two methoxy groups for 3 and a methyl and a methoxy group for 4, respectively. The placement of the methoxy and methyl groups was deduced from the HMBC experiments. In the HMBC spectrum of 3, clear correlations were observed between the methyl signal at $\delta 2.06 \mathrm{ppm}$, the $\mathrm{C}$ at $\delta 111.4(\mathrm{C}-4 \mathrm{a})$ and $\delta$ 157 ppm (C-5 and C-7), indicating that the methyl group was located at C-6. Correlation experiments allowed the assignation of the methoxy signals at $\delta 3.66$ and $\delta 3.75$ to the $C$ quartets at $\delta 59.9$ and $\delta 55.5 \mathrm{ppm}$, respectively. The methoxy signals show clear HMBC correlations with the $\mathrm{C}$ at $\delta 157.2$ and 157.3, assigned as C-8a and C-7. Further correlations were between the $\mathrm{H}$ singlet at $\delta 6.18$ and the $C$ at $\delta 154.0$ ppm and the $C$ at $\delta 154.3$ and the $H$ signals at $\delta 7.04$ and 6.76 from the $p$-substituted aromatic ring. The ${ }^{1} \mathrm{H}-\mathrm{NMR}$ spectrum of compound 4 was close to that of 3 , showing a methyl and a methoxy signal at $\delta 2.08$ and 3.67 ppm, respectively. The exact placement of the methyl and methoxy group follows from the HMBC experiments. Strong correlations were observed between the methyl signal at $\delta 2.08$ and the $C$ at $\delta 154.3$ and $\delta 157.2$ ppm as well as between the methoxy singlet at $\delta 3.67$ and the $C$ at $\delta$ 157.2. The $H$ singlet at $\delta 6.13$ showed clear correlation with the $C$ at $\delta 152.9$ ppm, while the doublets at $\delta 7.02$ and 6.77 from the $p$-substituted aromatic ring (C) shows correlation with the $C$ at 154.9 ppm, allowing the assignation of the oxygen-bearing aromatic $\mathrm{C}$ in the molecule. The HMBC correlation spectrum is shown in the Supplementary Materials. The ${ }^{13} \mathrm{C}-\mathrm{NMR}$ spectra (Table 2) are in agreement with the proposed structures. Compounds 3 and 4 were identified as 5,7-dimethoxy-6-methyl-3-(4-hydroxybenzyl)chroman and 7-hydroxy-5-methoxy-6-methyl-3-(4-hydroxybenzyl)chroman, respectively. The ${ }^{1} \mathrm{H}-\mathrm{NMR},{ }^{13} \mathrm{C}-\mathrm{NMR}$, HSQC and HMBC spectra of compounds 1, 3 and 4 are available in Figures S1-S12.

The ${ }^{1} \mathrm{H}-\mathrm{NMR}$ spectrum of compound $\mathbf{5}$ (Table 1 ) indicated identical aromatic substitution as in compound 1. However, instead of the $-\mathrm{OCH}_{2}-\mathrm{CH}$-(benzylic $\left.\mathrm{CH}_{2}\right)_{2}$ sequence observed for 1-4, three br $\mathrm{s}$ at $\delta 6.04(1 \mathrm{H}), 4.59(2 \mathrm{H})$ and $3.28 \mathrm{ppm}(2 \mathrm{H})$ indicates a double bond at $\mathrm{C}-3$. This assumption was supported by the ${ }^{13} \mathrm{C}-\mathrm{NMR}$ spectrum (Table 2$)$, showing an additional double bond ( $\delta 128.6 \mathrm{~s}$ and $\delta 119.6 \mathrm{~d}$ ) and the HR-EI-MS (calculated for $\mathrm{C}_{17} \mathrm{H}_{16} \mathrm{O}_{4}$ ) presenting a difference of one unsaturation degree with compound 1 . The placement of the methoxy group at C-8 was deduced by comparison with the related compound 1 as well as by the HMBC correlation of the methoxy group and the $C$ signal at $\delta$ 134.8. The compound 5 was assigned as 7-hydroxy-8-methoxy-3-(4-hydroxybenzyl)-3-chromen and is described for the first time.

The stereochemistry at C-3 of the new homoisoflavonoids was deduced by comparison with the optical rotation of reported homoisoflavonoids. According to [8], the stereochemistry of the homoisoflavans from Dracaena cinnabari showed positive circular dichroism at $280 \mathrm{~nm}$, indicating the same configuration for all the compounds. However, the absolute configuration by X-ray analysis was not possible [8]. The optical rotation for some of the derivatives was 0 , pointing out racemic mixtures. In the report on $D$. cambodiana phenolics [9], the structure of 7,4'-dihydroxyhomoisoflavane was given without stereochemistry. In the work on Dragon's Blood from D. draco [10], the compound 3-(4-dihydroxybenzyl)-5,7-dimethoxychroman was described without stereochemistry at C-3 but with optical rotation data, showing that the compound is dextrorotatory (+). The reported optical rotation for 7-hydroxy-3-(4-methoxybenzyl)chroman was (+) [11], showing a trend for this group of compounds. For the 6,4'-dihydroxy-8-methoxyhomoisoflavan, the absolute configuration at C-3 was reported as (3R) and the compound was dextrorotatory (+) [12]. Based on 
the optical rotation data and the absolute configuration reported by [12] the configuration at C-3 of the Herreria homoisoflavanes was assigned as (3R).

The structure of the compounds 6 and 7 follows the NMR spectra that show the typical signals for a flavan with a $p$-substituted B-ring and an aromatic $\mathrm{H}$ in the A-ring. The spectroscopic and spectrometric data of 6 and 7 are in agreement with $4^{\prime}, 5$-dihydroxy-7-methoxy-8-methylflavan 6 [7] and $4^{\prime}$-hydroxy-5,7-dimethoxy-8-methylflavan 7 [13]. The ${ }^{13} \mathrm{C}-\mathrm{NMR}$ data of compounds 6 and 7 is summarized in Table 2. The flavan 6 was previously isolated from the resin of Dracaena draco [7] and 7 was described from Pancratium maritimum [13]. The compounds 6 and 7 are related to (2S)-5,7-dihydroxy-4'-methoxy-8-methylflavan described from Dracaena cambodiana [14]. The closely related compound (2R)-7, $4^{\prime}$-dihydroxy-5-methoxy-8-methylflavan, differing in the relative placement of the $\mathrm{OH}$ and $\mathrm{OCH}_{3}$ functions at C-5 and C-7, was reported from Soymida febrifuga [12]. The compound 8, with a molecular formula $\mathrm{C}_{15} \mathrm{H}_{14} \mathrm{O}_{5}$ was identified as 3,3',5,5'-tetrahydroxy-4-methoxystilbene, previously isolated from Phoenix dactylifera (date palm) $[15,16]$.

Homoisoflavonoids have been isolated previously from the red resin of the Chinese crude drug Dragon's Blood. The resin is obtained from several botanical sources, including Palmaceae from genus Calamus and Daemonorops, Dracaenaceae (formerly Agavaceae) from genus Dracaena, Pterocarpus (Leguminosae) and Croton (Euphorbiaceae) species [17]. The chemistry of Dracaena species shows as constituents: homoisoflavonoids, flavonoid derivatives and steroids [16]. Homoisoflavonoids were reported from D. cinnabari [8], D. cambodiana [9] and D. draco [10]. The isolation of several stilbene derivatives and biflavonoid-like compounds was reported from D. cochinchinensis. The compounds showed effect against Helicobacter pylori and moderate thrombin inhibitory effect [17]. Homoisoflavonoids have been also isolated from the rhizomes of the Agavaceae Agave barbadensis [11] and from the bark of the Meliaceae Soymida febrifuga [12]. According to Dewick [18], related compounds isolated from Eucomis and Scilla species (Liliaceae) are biosynthetized from a chalcone-type skeleton by the addition of a carbon atom derived from methionine. Flavanes related to compound 4 with a $\mathrm{OCH}_{3}$ at $4^{\prime}$ were isolated from the rhizomes of Agave barbadensis [11] and from the stems of the Dracaena cambodiana [9]. Luo et al. [9] reported the antioxidant activity of D. cambodiana but the very high $\mathrm{SC}_{50}$ values found in the DPPH assay, compared with that or known antioxidants, indicates that they are not promising as antioxidant agents. In summary, the flavanes (homoisoflavonoids) occurring in H. montevidensis roots are similar to the constituents isolated from the crude drug Dragon's Blood obtained from the Dracaena species.

Compound 9 was isolated as yellow needles with a HR-EI-MS of 236.0950 atomic mass units, calculated for $\mathrm{C}_{15} \mathrm{H}_{12} \mathrm{~N}_{2} \mathrm{O}$. The molecular formula is in agreement with an alkaloid with eleven degrees of unsaturation. A singlet at $\delta 172.8 \mathrm{ppm}$ in the ${ }^{13} \mathrm{C}-\mathrm{NMR}$ spectrum (Table 3) indicates an $\alpha, \beta$-unsaturated carbonyl group. Six $\mathrm{C}$ signals can be associated with $\mathrm{sp}^{2} \mathrm{C}$ atoms belonging to an ortho-substituted phenyl ring while four $\mathrm{sp}^{2} \mathrm{C}$ builds an additional heterocyclic five-membered ring, compatible with an $\alpha$-substituted pyrrol. Two methylenes $t$ at $\delta 50.4$ and 25.4 ppm are part of an additional framework of the molecule. The ${ }^{1} \mathrm{H}-\mathrm{NMR}$ spectrum (Figure S13) shows three sequences including an ortho disubstituted aromatic ring, a $\alpha$-substituted pyrrole and two vicinal methylenes. All signals in the ${ }^{13} \mathrm{C}-\mathrm{NMR}$ spectrum were assigned with the aid of $2 \mathrm{D}$ experiments. The HMBC spectrum was helpful for the assignment of quaternary carbons and connections of fragments. The most important long range correlations were observed between $\mathrm{H}-7, \mathrm{H}-9, \mathrm{H}-6^{\prime}$ and N-H each with C-5, supporting the $2(1 H)$-quinolinone moiety of the compound (Figure S14). HMBC correlations and NOE experiments allowed the placement of the $\alpha$-substituted pyrrole and $-\mathrm{CH}_{2}-\mathrm{CH}_{2}-$ sequence in the compound, leading to structure 9. Among the dipolar interactions, those between $\mathrm{H}-6^{\prime}$ and $\mathrm{H}-6$, between $\mathrm{H}-5^{\prime}$ and $\mathrm{H}-3^{\prime}$ as well as between the $\mathrm{N}-\mathrm{H}$ and $\mathrm{H}-9$ should be emphasized for the characterization of the compound. All information is summarized in Table 3. The new compound belongs to a novel skeleton and is named herrerin in recognition of the plant source of the compound.

The structure of the compounds 10-16 was elucidated after acetylation which gave the secondary acetates. The ${ }^{1} \mathrm{H}-\mathrm{NMR}$ spectra of the compounds (Table 4) were similar, showing two angular methyl 
groups at $\delta 0.73-0.99$ and $\delta 0.90-1.15$ ppm, two methyl $\mathrm{d}$ at $\delta 0.76-1.08$ and $\delta 0.93-1.00$, two $\mathrm{H}$ associated with a primary alcohol/ether system (-OCH$\left.{ }_{2}-\mathrm{CH}-\right)$ in the range $\delta 3.30-3.93 \mathrm{ppm}$, a deshielded $\mathrm{H}$ signal at 4.34-4.63 ppm and the $\mathrm{H}$ belonging to the acetylated hydroxy functions at $\delta 5.02-5.10$ and $\delta 4.67-4.80 \mathrm{ppm}$. The ${ }^{13} \mathrm{C}-\mathrm{NMR}$ spectra (Table 5) suggest sapogenins of the spirostane type, characterized by the presence of a spiroketal ring system.

Table 3. NMR Spectral Data of Compound $9\left(400 \mathrm{MHz}\right.$ for ${ }^{1} \mathrm{H}$ - and $100 \mathrm{MHz}$ for ${ }^{13} \mathrm{C}-, \mathrm{CDCl}_{3}, \delta$-values in ppm, $J$ in $\mathrm{Hz}$ ).

\begin{tabular}{|c|c|c|c|c|c|}
\hline Position & $\delta_{C}$, Type & $\mathbf{H}$ & $\delta_{H}(J$ in $\mathrm{Hz})$ & НМВС & NOE \\
\hline 2 & $172.8 \mathrm{C}$ & & & & \\
\hline 3 & $132.7 \mathrm{C}$ & & & & \\
\hline 4 & $121.0 \mathrm{C}$ & & & & \\
\hline 5 & $127.2 \mathrm{C}$ & & & & \\
\hline 6 & $120.6 \mathrm{CH}$ & 6 & $7.66 \mathrm{~d}(8)$ & $4(\mathrm{w}), 5(\mathrm{w}), 8(\mathrm{~s}), 10(\mathrm{~s})$ & $6^{\prime}(3)$ \\
\hline 7 & $120.3 \mathrm{CH}$ & 7 & 7.17 ddd $(8,8,1)$ & $5(\mathrm{~s}), 9(\mathrm{~s})$ & \\
\hline 8 & $126.3 \mathrm{CH}$ & 8 & 7.36 ddd $(8,8,1)$ & $6(\mathrm{~s}), 10(\mathrm{~s})$ & \\
\hline 9 & $112.3 \mathrm{CH}$ & 9 & $7.46 \mathrm{~d}(8)$ & $5(\mathrm{~s}), 7(\mathrm{~s})$ & $\mathrm{N}-\mathrm{H}(3)$ \\
\hline 10 & $136.6 \mathrm{C}$ & & & & \\
\hline $1^{\prime}$ & $119.9 \mathrm{CH}$ & $1^{\prime}$ & $7.34 \mathrm{dd}(4,2)$ & $3^{\prime}(\mathrm{m}), 4^{\prime}(\mathrm{m})$ & \\
\hline $2^{\prime}$ & $109.3 \mathrm{CH}$ & $2^{\prime}$ & $6.26 \mathrm{dd}(4,2)$ & $1^{\prime}(\mathrm{w}), 3^{\prime}(\mathrm{s}), 4^{\prime}(\mathrm{s})$ & \\
\hline $3^{\prime}$ & $129.6 \mathrm{CH}$ & $3^{\prime}$ & $6.90 \mathrm{dd}(2,2)$ & $1^{\prime}(\mathrm{s}), 2^{\prime}(\mathrm{s}), 5^{\prime}(\mathrm{w}), 4^{\prime}(\mathrm{s})$ & $5^{\prime}(3)$ \\
\hline $4^{\prime}$ & $133.9 \mathrm{C}$ & - & & & \\
\hline $5^{\prime}$ & $50.4 \mathrm{CH}_{2}$ & $5^{\prime}$ & $4.48 \mathrm{~m}$ & $3^{\prime}(\mathrm{m}), 6^{\prime}(\mathrm{m}), 4^{\prime}(\mathrm{m}), 4(\mathrm{~s})$ & $3^{\prime}(5)$ \\
\hline $6^{\prime}$ & $25.4 \mathrm{CH}_{2}$ & $6^{\prime}$ & $3.40 \mathrm{~m}$ & $3(\mathrm{~s}), 4(\mathrm{~s}), 5(\mathrm{~s}), 5^{\prime}(\mathrm{m})$ & $6(5)$ \\
\hline $\mathrm{NH}$ & & & 9.45 br s & $5(w)$ & $9(5)$ \\
\hline
\end{tabular}

s: strong; m: medium; w: weak interaction.

According to [19], naturally occurring spirostanes can be classified into groups according to the following structural characteristics: stereochemistry at C-5, C-22 and C-25; relative placement and stereochemistry of the functional groups and position and number of double bonds, mainly for the $\Delta 5$ (5-en) derivatives. In the IR spectra, characteristic bands for the spiroketal system can be observed at $920-930 \mathrm{~cm}^{-1}$ for $(25 S)$, stronger than at $900-905 \mathrm{~cm}^{-1}$ for the $(25 R)$ spiroketal. In the ${ }^{1} \mathrm{H}-\mathrm{NMR}$ spectrum of compounds 10-13 and 15, two coupling ddd from the ester bearing centers require for each of them a vicinal $\mathrm{CH}_{2}$ group, supporting the sequence $-\mathrm{CH}_{2}-\mathrm{CHOAc}-\mathrm{CHOAc}-\mathrm{CH}_{2}-$ and the placement of the acetates at C-2 and C-3. The $J$ values of the coupling constants $J_{2,3}$ indicates a trans-diaxial arrangement of the $\mathrm{H}$ atoms (Table 4). Additional signals at $\delta 4.37-4.63$ and $\delta 3.30-3.93$ are typical for $\mathrm{H}-16$ and for both $\mathrm{H}-26$ hydrogen atoms. The $\mathrm{C}-25$ configuration can be deduced from the vicinal couplings from the geminal C-26 methylene protons (axial or equatorial position of the $\mathrm{H}$ in the vicinal position). For an equatorial methyl at C-25, the $J$ values are $J_{25,26}=5$ and $J_{25,26}=11 \mathrm{~Hz}$, respectively. The ${ }^{1} \mathrm{H}-\mathrm{NMR}$ spectra of the compounds 10 and 13 were very similar, showing two acetates at $\mathrm{H}-2$ and H-3 and differing in the chemical shift of the signals from $\mathrm{H}-26\left(-\mathrm{O}-\mathrm{CH}_{2}-\right)$ and the methyl $\mathrm{d}$ (H-27). Both compounds differ in the stereochemistry at C-25. The ${ }^{1} \mathrm{H}-$ and ${ }^{13} \mathrm{C}-\mathrm{NMR}$ data of the compounds are in agreement with the 2O,3O-diacetates of gitogenin ((25R)-5 $\alpha$-spirostan-2 $\alpha, 3 \beta$-diol) (10) and neogitogenin ((25S)-5 $\alpha$-spirostan-2 $\alpha, 3 \beta$-diol) (13), respectively [19]. A clear differentiation of both compounds is possible on the basis of the ${ }^{13} \mathrm{C}-\mathrm{NMR}$ spectra. The axial methyl group at C-25 in the S-series led to a high field shift of 3-4 ppm in the $\alpha$ - and $\beta$-position and due to the gauche effect about 5.5 ppm on the C-23 signal. The spirostane steroid gitogenin was previously isolated from Digitalis spp., Yucca gloriosa and Isoplexis canariensis while neogitogenin was reported from Digitalis, Yucca and other species [16].

The ${ }^{1} \mathrm{H}-\mathrm{NMR}$ spectra of $\mathbf{1 1}$ and $\mathbf{1 5}$ were similar to each other and differ from that of $\mathbf{1 0}$ and $\mathbf{1 3}$ by the occurrence of an additional $\mathrm{OH}$ function in $\mathbf{1 1}$ and 15. The splitting of the H-15 signal of 11 and 15 suggest that the hydroxy function is placed at C-14. The chemical shift of an additional downfield singlet at $\delta 87.9 \mathrm{ppm}$ in the ${ }^{13} \mathrm{C}-\mathrm{NMR}$ spectra confirmed this assumption. The stereochemistry of the $\mathrm{OH}$ function was deduced from the chemical shift of $\mathrm{H}-17$, which was shifted downfield due to the syn-planar orientation with the hydroxy group. 
Table 4. Selected ${ }^{1} \mathrm{H}-\mathrm{NMR}$ Spectral Data of Compounds 10-16 (400 MHz, $\mathrm{CDCl}_{3}, \delta$-values in ppm, J in Hz).

\begin{tabular}{|c|c|c|c|c|c|c|c|}
\hline Position & 10 & 11 & 12 & 13 & 14 & 15 & 16 \\
\hline 2 & 5.02 ddd $(12,10,5)$ & 5.03 ddd $(12,10,5)$ & 5.04 ddd $(12,10,5)$ & 5.02 ddd $(12,10,5)$ & $\ddagger$ & 5.03 ddd $(12,10,5)$ & $5.10 \mathrm{ddd}(12,10,5)$ \\
\hline 3 & 4.78 ddd $(11,10,5)$ & 4.79 ddd $(11,10,5)$ & 4.80 ddd $(11,10,5)$ & 4.78 ddd $(11,10,5)$ & 4.67 dddd $(11,11,4,4)$ & 4.79 ddd $(11,10,5)$ & 4.72 ddd $(11,10,5)$ \\
\hline 6 & $*$ & $*$ & $*$ & $*$ & $*$ & $*$ & $5.47 \mathrm{br}$ ddd $(5,2,2)$ \\
\hline $15 \alpha$ & $1.65 \mathrm{~m}$ & $1.94 \mathrm{dd}(13,8)$ & 4.10 ddd $(5,3,2)$ & $1.65 \mathrm{~m}$ & $1.94 \mathrm{dd}(13,8)$ & $1.94 \mathrm{dd}(13,8)$ & $\ddagger$ \\
\hline $15 \beta$ & $1.20 \mathrm{~m}$ & $1.59 \mathrm{dd}(13,6)$ & $15-\mathrm{OH}, 2.23 \mathrm{brs}$ & $1.20 \mathrm{~m}$ & $1.58 \mathrm{dd}(13,6)$ & $1.59 \mathrm{dd}(13,6)$ & $\ddagger$ \\
\hline 16 & 4.37 ddd $(8,8,6)$ & 4.62 ddd $(8,8,6)$ & $4.34 \mathrm{dd}(8,5)$ & 4.37 ddd $(8,8,6)$ & 4.63 ddd $(8,8,6)$ & 4.62 ddd $(8,8,6)$ & 4.62 ddd $(8,8,6)$ \\
\hline 17 & $1.75 \mathrm{dd}(8,7)$ & $2.31 \mathrm{dd}(8,7)$ & $1.94 \mathrm{dd}(8,7)$ & $1.75 \mathrm{dd}(8,7)$ & $2.31 \mathrm{dd}(8,7)$ & $2.31 \mathrm{dd}(8,7)$ & $2.32 \mathrm{dd}(8,7)$ \\
\hline 18 & $0.73 \mathrm{~s}$ & $0.90 \mathrm{~s}$ & $0.99 \mathrm{~s}$ & $0.73 \mathrm{~s}$ & $0.86 \mathrm{~s}$ & $0.90 \mathrm{~s}$ & $0.93 \mathrm{~s}$ \\
\hline 19 & $0.90 \mathrm{~s}$ & $0.95 \mathrm{~s}$ & $0.95 \mathrm{~s}$ & $0.90 \mathrm{~s}$ & $0.91 \mathrm{~s}$ & $0.95 \mathrm{~s}$ & $1.15 \mathrm{~s}$ \\
\hline 20 & $1.85 \mathrm{~m}$ & $1.90 \mathrm{~m}$ & $\ddagger$ & $1.80 \mathrm{~m}$ & $1.86 \mathrm{~m}$ & $1.86 \mathrm{~m}$ & $\ddagger$ \\
\hline 21 & $0.93 \mathrm{~d}(7)$ & $0.97 \mathrm{~d}(7)$ & $0.96 \mathrm{~d}(7)$ & $0.96 \mathrm{~d}(7)$ & $1.00 \mathrm{~d}(7)$ & $1.00 \mathrm{~d}(7)$ & $0.99 \mathrm{~d}(7)$ \\
\hline $26 \alpha$ & $3.34 \mathrm{dd}(11,11)$ & $3.36 \mathrm{dd}(11,11)$ & $3.38 \mathrm{dd}(11,11)$ & 3.27 brd (11) & 3.30 brd (11) & 3.30 brd (11) & $3.36 \mathrm{dd}(11,11)$ \\
\hline $26 \beta$ & 3.45 ddd $(11,5,2)$ & 3.48 ddd $(11,5,2)$ & 3.51 ddd $(11,5,2)$ & $3.92 \mathrm{dd}(11,3)$ & $3.93 \mathrm{dd}(11,3)$ & $3.93 \mathrm{dd}(11,3)$ & 3.48 ddd $(11,5,2)$ \\
\hline 27 & $0.76 \mathrm{~d}(7)$ & $0.79 \mathrm{~d}(7)$ & $0.80 \mathrm{~d}(7)$ & $1.05 \mathrm{~d}(7)$ & $1.08 \mathrm{~d}(7)$ & $1.08 \mathrm{~d}(7)$ & $0.79 \mathrm{~d}(7)$ \\
\hline \multirow[t]{2}{*}{ OAc } & $2.01 \mathrm{~s}$ & $2.01 \mathrm{~s}$ & $2.01 \mathrm{~s}$ & $2.01 \mathrm{~s}$ & $2.01 \mathrm{~s}$ & $2.01 \mathrm{~s}$ & $2.01 \mathrm{~s}$ \\
\hline & $2.00 \mathrm{~s}$ & $2.01 \mathrm{~s}$ & $2.00 \mathrm{~s}$ & $2.00 \mathrm{~s}$ & - & $2.01 \mathrm{~s}$ & $2.00 \mathrm{~s}$ \\
\hline
\end{tabular}

${ }^{*}$ overlapped multiplet; ${ }^{\ddagger}$ not estimated. 
Table 5. ${ }^{13} \mathrm{C}$-NMR Spectral Data of Compounds 10-16 (100 MHz, $\mathrm{CDCl}_{3}, \delta$-values in ppm).

\begin{tabular}{|c|c|c|c|c|c|c|c|}
\hline Position & 10 & 11 & 12 & 13 & 14 & 15 & 16 \\
\hline 1 & $42.1 \mathrm{t}$ & $42.4 \mathrm{t}$ & $42.1 \mathrm{t}$ & $42.3 \mathrm{t}$ & $36.8 \mathrm{t}$ & $42.3 \mathrm{t}$ & $42.3 \mathrm{t}$ \\
\hline 2 & $71.6 \mathrm{~d}$ & $71.8 \mathrm{~d}$ & $71.8 \mathrm{~d}$ & $71.9 \mathrm{~d}$ & $28.3 \mathrm{t}$ & $71.8 \mathrm{~d}$ & $74.3 \mathrm{~d}$ \\
\hline 3 & $74.4 \mathrm{~d}$ & $74.5 \mathrm{~d}$ & $74.5 \mathrm{~d}$ & $74.6 \mathrm{~d}$ & $73.5 \mathrm{~d}$ & $74.5 \mathrm{~d}$ & $71.4 \mathrm{~d}$ \\
\hline 4 & $32.5 \mathrm{t}$ & $32.8 \mathrm{t}$ & $32.6 \mathrm{t}$ & $32.7 \mathrm{t}$ & $33.9 \mathrm{t}$ & $32.7 \mathrm{t}$ & $36.2 \mathrm{t}$ \\
\hline 5 & $43.9 \mathrm{~d}$ & $43.9 \mathrm{~d}$ & $44.2 \mathrm{~d}$ & $44.1 \mathrm{~d}$ & $44.3 \mathrm{~d}$ & $43.8 \mathrm{~d}$ & $137.1 \mathrm{~s}$ \\
\hline 6 & $27.4 \mathrm{t}$ & $27.4 \mathrm{t}$ & $27.4 \mathrm{t}$ & $27.5 \mathrm{t}$ & $27.4 \mathrm{t}$ & $27.4 \mathrm{t}$ & $123.4 \mathrm{~d}$ \\
\hline 7 & $31.5 \mathrm{t}$ & $26.7 t$ & $31.1 \mathrm{t}$ & $31.6 \mathrm{t}$ & $26.9 \mathrm{t}$ & $26.7 t$ & $26.0 \mathrm{t}$ \\
\hline 8 & $34.2 \mathrm{~d}$ & $37.8 \mathrm{~d}$ & $30.5 \mathrm{~d}$ & $34.3 \mathrm{~d}$ & $38.4 \mathrm{~d}$ & $37.7 \mathrm{~d}$ & $34.3 \mathrm{~d}$ \\
\hline 9 & $53.8 \mathrm{~d}$ & $46.6 \mathrm{~d}$ & $54.5 \mathrm{~d}$ & $54.0 \mathrm{~d}$ & $46.7 \mathrm{~d}$ & $46.6 \mathrm{~d}$ & $43.0 \mathrm{~d}$ \\
\hline 10 & $36.9 \mathrm{~s}$ & $37.3 \mathrm{~s}$ & $37.2 \mathrm{~s}$ & $37.1 \mathrm{~s}$ & $35.8 \mathrm{~s}$ & $37.3 \mathrm{~s}$ & $38.3 \mathrm{~s}$ \\
\hline 11 & $21.0 \mathrm{t}$ & $20.1 \mathrm{t}$ & $21.3 \mathrm{t}$ & $21.1 \mathrm{t}$ & $20.0 \mathrm{t}$ & $20.1 \mathrm{t}$ & $19.7 \mathrm{t}$ \\
\hline 12 & $39.6 \mathrm{t}$ & $31.8 \mathrm{t}$ & $42.1 \mathrm{t}$ & $39.8 \mathrm{t}$ & $31.9 \mathrm{t}$ & $31.8 \mathrm{t}$ & $31.4 \mathrm{t}$ \\
\hline 13 & $40.3 \mathrm{~s}$ & $44.5 \mathrm{~s}$ & $40.6 \mathrm{~s}$ & $40.4 \mathrm{~s}$ & $44.5 \mathrm{~s}$ & $44.5 \mathrm{~s}$ & $44.3 \mathrm{~s}$ \\
\hline 14 & $55.8 \mathrm{~d}$ & $87.9 \mathrm{~s}$ & $60.2 \mathrm{~d}$ & $56.0 \mathrm{~d}$ & $88.1 \mathrm{~s}$ & $87.9 \mathrm{~s}$ & $87.1 \mathrm{~s}$ \\
\hline 15 & $31.7 \mathrm{t}$ & $39.5 \mathrm{t}$ & $69.6 \mathrm{~d}$ & $31.8 \mathrm{t}$ & $39.3 \mathrm{t}$ & $39.4 \mathrm{t}$ & $39.3 \mathrm{~s}$ \\
\hline 16 & $80.6 \mathrm{~d}$ & $80.8 \mathrm{~d}$ & $82.0 \mathrm{~d}$ & $80.8 \mathrm{~d}$ & $81.0 \mathrm{~d}$ & $80.9 \mathrm{~d}$ & $80.7 \mathrm{~d}$ \\
\hline 17 & $61.7 \mathrm{~d}$ & $58.7 \mathrm{~d}$ & $61.1 \mathrm{~d}$ & $61.9 \mathrm{~d}$ & $58.5 \mathrm{~d}$ & $58.5 \mathrm{~d}$ & $58.8 \mathrm{~d}$ \\
\hline 18 & $16.3 \mathrm{q}$ & $20.1 \mathrm{q}$ & $19.0 \mathrm{q}$ & $16.4 \mathrm{q}$ & $20.2 \mathrm{q}$ & $20.1 \mathrm{q}$ & $19.8 \mathrm{q}$ \\
\hline 19 & $12.8 \mathrm{q}$ & $12.8 \mathrm{q}$ & $12.8 \mathrm{q}$ & $12.9 \mathrm{q}$ & $12.1 \mathrm{q}$ & $12.8 \mathrm{q}$ & $14.7 \mathrm{q}$ \\
\hline 20 & $41.4 \mathrm{~d}$ & $41.6 \mathrm{~d}$ & $42.4 \mathrm{~s}$ & $42.1 \mathrm{~d}$ & $42.1 \mathrm{~d}$ & $42.1 \mathrm{~d}$ & $41.6 \mathrm{~d}$ \\
\hline 21 & $14.2 \mathrm{q}$ & $14.7 \mathrm{q}$ & $14.2 \mathrm{q}$ & $14.3 \mathrm{q}$ & $14.5 \mathrm{q}$ & $14.5 \mathrm{q}$ & $14.7 \mathrm{q}$ \\
\hline 22 & $109.0 \mathrm{~s}$ & $109.5 \mathrm{~s}$ & $110.0 \mathrm{~s}$ & $109.6 \mathrm{~s}$ & $109.9 \mathrm{~s}$ & $109.9 \mathrm{~s}$ & $109.5 \mathrm{~s}$ \\
\hline 23 & $31.2 \mathrm{t}$ & $31.5 \mathrm{t}$ & $31.1 \mathrm{t}$ & $25.7 \mathrm{t}$ & $25.8 \mathrm{t}$ & $25.8 \mathrm{t}$ & $31.4 \mathrm{t}$ \\
\hline 24 & $28.6 \mathrm{t}$ & $28.8 \mathrm{t}$ & $28.5 \mathrm{t}$ & $25.9 \mathrm{t}$ & $26.0 \mathrm{t}$ & $26.0 \mathrm{t}$ & $28.8 \mathrm{t}$ \\
\hline 25 & $30.1 \mathrm{~d}$ & $30.2 \mathrm{~d}$ & $30.1 \mathrm{~d}$ & $27.0 \mathrm{~d}$ & $27.0 \mathrm{~d}$ & $27.0 \mathrm{~d}$ & $30.2 \mathrm{~d}$ \\
\hline 26 & $66.6 \mathrm{t}$ & $66.8 \mathrm{t}$ & $67.1 \mathrm{t}$ & $65.1 \mathrm{t}$ & $65.1 \mathrm{t}$ & $65.1 \mathrm{t}$ & $66.8 \mathrm{t}$ \\
\hline 27 & $17.0 \mathrm{q}$ & $17.1 \mathrm{q}$ & $17.0 \mathrm{q}$ & $16.0 \mathrm{q}$ & $16.1 \mathrm{q}$ & $16.1 \mathrm{q}$ & $17.1 \mathrm{~d}$ \\
\hline \multirow[t]{2}{*}{ OAc } & $170.3 \mathrm{~s}$ & $170.6 \mathrm{~s}$ & $170.5 \mathrm{~s}$ & $170.6 \mathrm{~s}$ & $170.7 \mathrm{~s}$ & $170.6 \mathrm{~s}$ & $170.5 \mathrm{~s}$ \\
\hline & $21.0 \mathrm{q}$ & $21.1 \mathrm{q}$ & $21.1 \mathrm{q}$ & $21.1 \mathrm{q}$ & $21.5 \mathrm{q}$ & $21.1 \mathrm{q}$ & $21.2 \mathrm{q}$ \\
\hline \multirow[t]{2}{*}{ OAc } & $170.2 \mathrm{~s}$ & $170.6 \mathrm{~s}$ & $170.4 \mathrm{~s}$ & $170.5 \mathrm{~s}$ & - & $170.6 \mathrm{~s}$ & $170.4 \mathrm{~s}$ \\
\hline & $21.0 \mathrm{q}$ & $21.2 \mathrm{q}$ & $21.1 \mathrm{q}$ & $21.1 \mathrm{q}$ & - & $21.2 \mathrm{q}$ & $21.1 \mathrm{q}$ \\
\hline
\end{tabular}

Compounds $\mathbf{1 1}$ and $\mathbf{1 5}$ differ in the stereochemistry of the H-27 methyl group as can be deduced from the chemical shift of the $\mathrm{H}-26$ and $\mathrm{H}-27$ signals. The compounds were assigned as $14 \alpha$-hydroxygitogenin

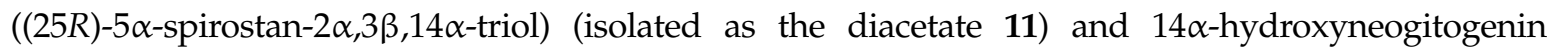
((25S)-5 $\alpha$-spirostan-2 $\alpha, 3 \beta, 14 \alpha$-triol) (isolated as the diacetate 15). Both compounds are reported for the first time as natural products. Compound 12, with hydroxy functions at H-2 and H-3, differ from 11 in the placement of the third $\mathrm{OH}$ function. While compound 11 presents a tertiary alcohol at $\mathrm{C}-14$, compound 12 shows the additional $\mathrm{OH}$ group at $\mathrm{C}-15$ and was identified as digitogenin.

The ${ }^{1} \mathrm{H}-\mathrm{NMR}$ spectrum of $\mathbf{1 4}$ differs from the other spirostane steroids from the plant by the absence of the downfield shifted $\mathrm{H}-2$ signal and the presence of only one acetate. The ${ }^{13} \mathrm{C}-\mathrm{NMR}$ data allowed the assignation of the signals by comparison with the data reported by [19] for steroidal sapogenins. The s at $\delta 88.1 \mathrm{ppm}$ in the ${ }^{13} \mathrm{C}-\mathrm{NMR}$ spectrum indicates that the second $\mathrm{OH}$ function is placed at C-14. The multiplicity of the H-3 signal and the chemical shift of the H-26 protons are in agreement with $14 \alpha$-hydroxy neotigogenin ((25S)-5 $\alpha$-spirostan-3 $\alpha, 14 \alpha$-diol) (as the acetate 14). The ${ }^{1} \mathrm{H}-\mathrm{NMR}$ spectrum of compound 16 was similar to that of compound 11, differing by the olefinic br ddd signal at $\delta 5.47 \mathrm{ppm}(J=5,2,2 \mathrm{~Hz})$, assigned to $\mathrm{H}-6$, and by the ${ }^{13} \mathrm{C}$ spectrum that showed a double bond at $\delta 137.1$ (s) and 123.4 (d) ppm for compound 16. The structural feature is typical for H-5 in steroids, supporting the $\Delta^{5}$ derivative of 11. The ${ }^{13} \mathrm{C}-\mathrm{NMR}$ data is in agreement with the assignation. The compound was identified as $14 \alpha$-hydroxy-yuccagenin ((25R)-spirost-5-en-2 $\alpha, 3 \beta, 14 \alpha$-triol). The steroidal sapogenins 11, 14-16 were not found in the consulted databases (SciFinder and Dictionary of Natural Products on DVD [16]) and to the best of our knowledge are reported for the first time. 
The stereochemistry at C-20 from all the isolated spirostane was deduced on the basis of the NOE experiments. Clear effects were observed between $\mathrm{H}-21$ and $\mathrm{H}-17$ as well as between H-16 and H-17. The stereochemistry at C-22 was confirmed on the basis of the ${ }^{13} \mathrm{C}-\mathrm{NMR}$ data compared with the literature. The NOE effect between H-19 and H-2 confirm the occurrence of $5 \alpha$-spirostane. Spirostane steroids, also known as sapogenins occurs in the Liliaceae, Amaryllidaceae and Dioscoreaceae families from the Monocots as well as in some Dicot families such as the Scrophulariaceae and Solanaceae. They are frequently linked with sugars to build saponins. Sapogenins are used for the commercial attainment of steroidal hormones, being diosgenin from Dioscorea species the most important starting product [16].

The rhizome of Herreria montevidensis was formerly included in the same group of sources as the crude drug "zarzaparrilla" as a Smilax species. Both of them have in common the traditional use as a diuretic and depurative, in Asia as well as in the Americas. Brandao et al. [20] refer to the Brazilian plants described by European naturalists in the 19th century, including "zarzaparrilla". The common name refers to Smilax and Herreria species. A recent work on Smilax brasiliensis and Herreria salsaparrilha from Brazil showed a positive impact of the crude drugs' extracts on the triglyceride levels in high-refined carbohydrate diets in mice [21] as well as on the glucose and cholesterol levels in treated animals. The authors detected saponins but also chlorogenic acid and known phenolics in the extracts.

Rhizomes from several Smilax species are used in traditional Asian medicine. Some of them contain phenylpropanoids that are active towards $\beta$-secretase [22], antioxidant and cytotoxic glycosides [23] or present anti-estrogenic/estrogenic activity [24], among other effects. Spirostane saponins also present anti-inflammatory activity [25]. The chemical diversity found in the H. montevidensis roots from the Paraguayan Chaco suggests the potential of the crude drug constituents as bioactive agents.

\section{Experimental Section}

\subsection{General Experimental Procedures}

Melting points were determined on a Koffler hot stage apparatus (Electrothermal 9100, Dubuque, IA, USA) and were uncorrected. IR spectra were recorded on a Nicolet Nexus 470 FT-IR instrument (Thermo Electron Corporation, Waltham, MA, USA). The NMR spectra were recorded on an Avance 400 spectrometer (Bruker, Rheinstetten, Germany) at $400 \mathrm{MHz}$ for ${ }^{1} \mathrm{H}$ and $100 \mathrm{MHz}$ for ${ }^{13} \mathrm{C}$ - in $\mathrm{CDCl}_{3}$ or $\mathrm{CDCl}_{3}$-methanol- $d_{4}$. Chemical shifts are given in ppm with residual chloroform as the internal standard. High-resolution mass spectra were measured on a VG Micromass ZAB-2F at $70 \mathrm{eV}$ (Varian Inc., Palo Alto, CA, USA). Merck silica gel (0.063-0.2) was used for column chromatography. Pre-coated Si gel plates (Kieselgel 60 F254, 0.25 mm, Merck, Darmstadt, Germany) were used for TLC analysis. TLC spots were visualized by spraying the chromatograms with $p$-anisaldehyde-ethanol-acetic acid $-\mathrm{H}_{2} \mathrm{SO}_{4}(2: 170: 20: 10 \mathrm{v} / \mathrm{v})$ and heating at $110{ }^{\circ} \mathrm{C}$ for $3 \mathrm{~min}$.

\subsection{Plant Material}

The roots of Herreria montevidensis Klotzsch ex Griseb. were collected in the outskirts of the Ayoreo settlement of Isla Alta, Departamento Alto Paraguay, Paraguay, in December, 1991. Voucher herbarium specimens (Schmeda 1408) were identified by S. Smith (Smithsonian Institution, Washington, DC, USA) where they have been deposited.

\subsection{Extraction and Isolation}

The air-dried roots $(750 \mathrm{~g})$ were powdered and extracted with EtOAc-MeOH 1:1 $(3 \times 5 \mathrm{~L})$ to give a crude extract which was partitioned between $\mathrm{CHCl}_{3}$ and $\mathrm{H}_{2} \mathrm{O}$. The $\mathrm{CHCl}_{3}$-soluble fraction (7.5 g) was chromatographed on a medium pressure silica gel column with a petroleum ether- diethyl ether-EtOAc-MeOH gradient, to give 40 fractions of $250 \mathrm{~mL}$ each. The first group of fractions did not contain compounds of interest and were discarded. Fraction 1 yielded after preparative HPLC (RP8, 
$\mathrm{MeOH}-\mathrm{H}_{2} \mathrm{O}$ 7:3), $3 \mathrm{mg} 7\left(R_{\mathrm{t}} 5.4 \mathrm{~min}\right)$ and $18 \mathrm{mg} 3\left(R_{\mathrm{t}} 9.1 \mathrm{~min}\right.$.). Compound 9 (11 mg) eluted in fraction 12 and recrystallized from $\mathrm{MeOH}$.

Fractions 14-16 were combined and rechromatographed on $\mathrm{SiO}_{2}$ with a PE/EtOAc gradient to give 20 fractions. Fractions 10-14 were further purified on Sephadex LH-20 with MeOH. Fractions 12-13 from the Sephadex column yielded $7 \mathrm{mg}$ 1, while fractions 14-15 afforded after HPLC (RP8, $\left.\mathrm{MeOH}-\mathrm{H}_{2} \mathrm{O} 1: 1\right) 4 \mathrm{mg} 1\left(R_{\mathrm{t}} 5.6 \mathrm{~min}\right)$ and $3 \mathrm{mg} 7\left(R_{\mathrm{t}} 7.3 \mathrm{~min}\right)$. Fractions 16-18 afforded after HPLC (RP8, MeOH-H $\left.{ }_{2} \mathrm{O} 1: 1\right) 3 \mathrm{mg} 2\left(R_{\mathrm{t}} 6.3 \mathrm{~min}\right), 4 \mathrm{mg} 6\left(R_{\mathrm{t}} 7.0 \mathrm{~min}\right)$ and $20 \mathrm{mg} 4\left(R_{\mathrm{t}} 8.2 \mathrm{~min}\right)$. Fractions 19-25 afforded after HPLC (RP8, MeOH- $\left.\mathrm{H}_{2} \mathrm{O} 1: 1\right) 3 \mathrm{mg} 6$ ( $\left.R_{\mathrm{t}} 6.5 \mathrm{~min}\right)$.

Fractions 23-25 from the first silica gel column were acetylated and chromatographed on a medium pressure silica gel column with a petroleum ether (PE)/methyl tert-butyl ether (MTBE) gradient. Fractions 2-3 (130 mg) afforded a mixture of the acetates 10 and 13. Some $60 \mathrm{mg}$ from the fractions 2-3 yielded after preparative HPLC (PE-MTBE; 9.5:1.5) $15 \mathrm{mg}$ of a 10/13 (3:1) mixture $\left(R_{\mathrm{t}} 11.6 \mathrm{~min}\right), 20 \mathrm{mg} \mathrm{10/13}(1: 3)$ mixture $\left(R_{\mathrm{t}} 17.2 \mathrm{~min}\right)$ and $6 \mathrm{mg} 13\left(R_{\mathrm{t}} 21.5 \mathrm{~min}\right)$. Fractions 4 and 5 afforded $186 \mathrm{mg} \mathrm{12}$. Fractions 8 and 9 afforded $12 \mathrm{mg} \mathrm{14}$. Fraction 11 yielded $8 \mathrm{mg}$ 16. Fraction 13 afforded $60 \mathrm{mg} \mathbf{1 1}$ and fraction 15 yielded $17 \mathrm{mg} \mathbf{1 5}$.

The aqueous phase from the total extract partition was lyophilized and the resulting powder was extracted with $\mathrm{MeOH}$. The $\mathrm{MeOH}$-soluble fraction (12 g) was chromatographed on a medium pressure silica gel column with a petroleum ether-diethyl ether-EtOAc-MeOH gradient to give 50 fractions of $250 \mathrm{~mL}$ each. Fractions 11 and 12 yielded after HPLC (RP8, MeOH- $\mathrm{H}_{2} \mathrm{O}$ 7:3) $26 \mathrm{mg} \mathbf{1}$ and $8 \mathrm{mg} 5$. Gel permeation of fractions 15-18 on Sephadex LH-20 with MeOH yielded 15 mg 8. Known compounds were identified by comparing their spectral data with those of authentic material or with literature data.

\subsection{Compound Characterization}

(3R)-7-Hydroxy-8-methoxy-3-(4-hydroxybenzyl)chroman (1). Colorless resin; ${ }^{1} \mathrm{H}-\mathrm{NMR}$ and ${ }^{13} \mathrm{C}-\mathrm{NMR}$ see Tables 1 and 2; EI-MS: $m / z$ (rel. int.): $286[\mathrm{M}]^{+}(100), 178\left[\mathrm{M}-\mathrm{C}_{6} \mathrm{H}_{4}(\mathrm{OH}) \mathrm{CH}_{3}\right]^{+}(40), 107$ [C $_{7} \mathrm{H}_{7} \mathrm{O}$ hydroxytropylium] $]^{+}$(100); HR-EI-MS 286.1205 (calcd. for $\mathrm{C}_{17} \mathrm{H}_{18} \mathrm{O}_{4}, 286.1205$ ).

(3R)-7-Methoxy-3-(4-hydroxybenzyl)chroman (2). Colorless resin; ${ }^{1} \mathrm{H}-\mathrm{NMR}$ and ${ }^{13} \mathrm{C}-\mathrm{NMR}$ see Tables 1 and 2; EI-MS $m / z$ (rel. int.): $270[\mathrm{M}]^{+}$(100), $162\left[\mathrm{M}-\mathrm{C}_{6} \mathrm{H}_{4}(\mathrm{OH}) \mathrm{CH}_{3}\right]^{+}$(40), 107 $\left[\mathrm{C}_{7} \mathrm{H}_{7} \mathrm{O} \text { hydroxytropylium }\right]^{+}$(100); HR-EI-MS 270.1256 (calcd. for $\mathrm{C}_{17} \mathrm{H}_{18} \mathrm{O}_{3}, 270.1256$ ); $[\alpha]_{24}^{D}=(+) 30.0$ $\left(c=2 \times 10^{-3} \mathrm{~g} / 100 \mathrm{~mL}, \mathrm{MeOH}\right)$.

(3R)-5,7-Dimethoxy-6-methyl-3-(4-hydroxybenzyl)chroman (3). Colorless resin; ${ }^{1} \mathrm{H}-\mathrm{NMR}$ and ${ }^{13} \mathrm{C}-\mathrm{NMR}$ see Tables 1 and 2; EI-MS $m / z$ (rel. int.): $314[\mathrm{M}]^{+}$(100), $206\left[\mathrm{M}-\mathrm{C}_{6} \mathrm{H}_{4}(\mathrm{OH}) \mathrm{CH}_{3}\right]^{+}$(35), 107 $\left[\mathrm{C}_{7} \mathrm{H}_{7} \mathrm{O}\right.$ hydroxytropylium] ${ }^{+}$(30); HR-EI-MS 314.1518 (calcd. for $\mathrm{C}_{19} \mathrm{H}_{22} \mathrm{O}_{4}, 314.1518$ ). $[\alpha]_{24}^{D}=(+) 50.7$ $\left(c=15 \times 10^{-3} \mathrm{~g} / 100 \mathrm{~mL}, \mathrm{MeOH}\right)$.

(3R)-7-Hydroxy-5-methoxy-6-methyl-3-(4-hydroxybenzyl)chroman (4). Colorless resin; ${ }^{1} \mathrm{H}-\mathrm{NMR}$ and ${ }^{13} \mathrm{C}-\mathrm{NMR}$ see Tables 1 and 2; EI-MS $m / z$ (rel. int.): $300[\mathrm{M}]^{+}(100), 192\left[\mathrm{M}-\mathrm{C}_{6} \mathrm{H}_{4}(\mathrm{OH}) \mathrm{CH}_{3}\right]^{+}(30), 107$ $\left[\mathrm{C}_{7} \mathrm{H}_{7} \mathrm{O} \text { hydroxytropylium }\right]^{+}$(30); HR-EI-MS 300.1362 (calcd. for $\mathrm{C}_{18} \mathrm{H}_{20} \mathrm{O}_{4}, 300.1362$ ). $[\alpha]_{24}^{\mathrm{D}}=(+) 53.8$ $\left(c=21 \times 10^{-3} \mathrm{~g} / 100 \mathrm{~mL}, \mathrm{MeOH}\right)$.

7-Hydroxy-8-methoxy-3-(4-hydroxybenzyl)-3-chromen (5). Pale yellow resin; ${ }^{1} \mathrm{H}-\mathrm{NMR}$ and ${ }^{13} \mathrm{C}-\mathrm{NMR}$ see Tables 1 and 2; EI-MS $m / z$ (rel. int.): $284[\mathrm{M}]^{+}(100), 177\left[\mathrm{M}-\mathrm{C}_{6} \mathrm{H}_{4}(\mathrm{OH}) \mathrm{CH}_{2}\right]^{+}(100), 107$ $\left[\mathrm{C}_{7} \mathrm{H}_{7} \mathrm{O} \text { hydroxytropylium }\right]^{+}$(85); HR-EI-MS 284.1059 (calcd. for $\mathrm{C}_{17} \mathrm{H}_{16} \mathrm{O}_{4}, 284.1059$ ). $[\alpha]_{24}^{\mathrm{D}}=(+) 48.5$ $\left(c=8 \times 10^{-3} \mathrm{~g} / 100 \mathrm{~mL}, \mathrm{MeOH}\right)$.

Herrerin (9). Yellow needles, m.p. $228{ }^{\circ} \mathrm{C} ;{ }^{1} \mathrm{H}-\mathrm{NMR}$ and ${ }^{13} \mathrm{C}-\mathrm{NMR}$ see Table 3; IR $v_{\max }$ (KBr) 3307, 2936, 1580, 1571, 1473, 1442, 1357, 1311, 1251, 1163, 1115, 1049, 963, 731, 673, 549, $433 \mathrm{~cm}^{-1}$; EI-MS $m / z$ (rel. int.): $236[\mathrm{M}]^{+}$(98), 207 (14), $143\left[\mathrm{M}-\mathrm{C}_{8} \mathrm{H}_{7} \mathrm{~N}\right]^{+}$(100); HR-EI-MS 236.0950 (calcd. for $\left.\mathrm{C}_{15} \mathrm{H}_{12} \mathrm{~N}_{2} \mathrm{O}, 236.0950\right)$. 
$14 \alpha$-Hydroxygitogenin ((25R)-5 $\alpha$-Spirostan-2 $\alpha, 3 \beta, 14 \alpha$-triol) (11) isolated as 2O,3O-diacetate. White solid, ${ }^{1} \mathrm{H}-\mathrm{NMR}$ and ${ }^{13} \mathrm{C}-\mathrm{NMR}$ see Tables 4 and 5; IR $v_{\max }(\mathrm{KBr}) 3564,2929,2859,1741,1450,1368,1252,1180$, $1134,1098,1043,981,902,869,734,675,609 \mathrm{~cm}^{-1}$; EI-MS m/z (rel. int.): 516 [M] $^{+}(12), 457$ [M - OAc] $^{+}$ (6), 444 (20), 402 (18), 387 (28), 373 (32), 149 (56), 139 [ $\left.\mathrm{C}_{9} \mathrm{H}_{15} \mathrm{O}\right]^{+}$(100); HR-EI-MS 516.3451 (calcd. for $\left.\mathrm{C}_{31} \mathrm{H}_{48} \mathrm{O}_{6}, 516.3451\right)$.

14 $\alpha$-Hydroxyneotigogenin ((25S)-5 $\alpha$-Spirostan-3 $\beta, 14 \alpha$-diol) (14) isolated as 3O-acetate. White solid, ${ }^{1} \mathrm{H}-\mathrm{NMR}$ and ${ }^{13} \mathrm{C}-\mathrm{NMR}$ see Tables 4 and 5; EI-MS $m / z$ (rel. int.): 516 [M] ${ }^{+}(12), 457$ [M - OAc] ${ }^{+}$ (6), 444 (20), 402 (18), 387 (28), 373 (32), 149 (56), $139\left(\mathrm{C}_{9} \mathrm{H}_{15} \mathrm{O}\right)^{+}$(100); HR-EI-MS 516.3451 (calcd. for $\left.\mathrm{C}_{31} \mathrm{H}_{48} \mathrm{O}_{6}, 516.3451\right)$.

14 $\alpha$-Hydroxyneogitogenin ((25S)-5 $\alpha$-Spirostan-2 $\alpha, 3 \beta, 14 \alpha$-triol) (15) isolated as 2O,3O-diacetate. White solid, ${ }^{1} \mathrm{H}-\mathrm{NMR}$ and ${ }^{13} \mathrm{C}-\mathrm{NMR}$ see Tables 4 and 5; IR $v_{\max }(\mathrm{KBr}) 3542,2941,1743,1729,1449,1371,1307$, 1232, 1178, 1133, 1059, 1001, 945, 920, 900, 866, 735, 678, 649, $605 \mathrm{~cm}^{-1}$; EI-MS m/z (rel. int.): 532 [M] ${ }^{+}$ (12), $514\left[\mathrm{M}-\mathrm{H}_{2} \mathrm{O}\right]^{+}(5), 473[\mathrm{M}-\mathrm{OAc}]^{+}(10), 460(20), 418\left[_{460}-\right.$ ketene $^{+}(15), 400\left[460-\mathrm{AcOH}^{+}\right.$

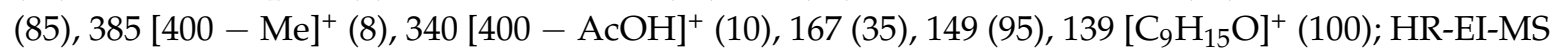
532.3400 (calcd. for $\mathrm{C}_{31} \mathrm{H}_{48} \mathrm{O}_{7}, 532.3400$ ).

$14 \alpha$-Hydroxyyuccagenin ((25R)-Spirost-5-en-2 $\alpha, 3 \beta, 14 \alpha$-triol) (16) isolated as 2O,3O-diacetate. White solid, ${ }^{1} \mathrm{H}-\mathrm{NMR}$ and ${ }^{13} \mathrm{C}$-NMR see Tables 4 and 5; IR $v_{\max }(\mathrm{KBr}) 3550,2951,2872,1738,1455,1369,1239,1180$, 1101, 1053, 980, 919, 900, 869, 732, 648, $606 \mathrm{~cm}^{-1}$. EI-MS m/z (rel. int.): $530\left[\mathrm{M}^{+}(1), 512\left[\mathrm{M}-\mathrm{H}_{2} \mathrm{O}\right]^{+}\right.$ $(1), 452\left[512-\mathrm{AcOH}^{+}\right.$(4), $392\left[452-\mathrm{AcOH}^{+}(12), 377\left[392-\mathrm{Me}^{+}(45), 177(68), 139\left[\mathrm{C}_{9} \mathrm{H}_{15} \mathrm{O}\right]^{+}(50)\right.\right.$, 43 (100); HR-EI-MS 530.3244 (calcd. for $\mathrm{C}_{31} \mathrm{H}_{46} \mathrm{O}_{7}, 530.3244$ ).

\section{Conclusions}

Several new compounds, including the rare homoisoflavanes 2-5, a new alkaloid 9 belonging to a novel skeleton type and three new spirostane steroids 11, 15 and $\mathbf{1 6}$ were isolated and identified from the roots of $H$. montevidensis. The findings show clear chemotaxonomic relations with the Liliaceae and Agavaceae plant family, but with distinctive compounds that up to this point have not been identified in other species. To confirm the possible effect of the crude drug in traditional medicine, additional studies are needed, including bioactivity testing using suitable bioassays and chemical profiling of the extracts using hyphenated techniques.

Supplementary Materials: The following are available online at www.mdpi.com/1420-3049/21/11/1589/s1.

Acknowledgments: M.D.-B. thanks the CNPq (Brazil) for a Doctoral grant. We are grateful to the Programa de Investigación de Excelencia Interdisciplinaria (PIEI-QUIM-BIO), Universidad de Talca for financial support. We also thank the Academic Writing Center in the Programa de Idiomas of the Universidad de Talca (Rachael Jiménez-Lange) for the English corrections.

Author Contributions: María Dutra-Behrens isolated the compounds, worked on the structural elucidation and participated in the manuscript writing. Guillermo Schmeda-Hirschmann collected the plant, prepared the extracts, carried out the preliminary isolation, worked on the structural elucidation and wrote the manuscript.

Conflicts of Interest: The authors declare no conflict of interest.

\section{References}

1. Schmeda-Hirschmann, G. Magic and medicinal plants of the Ayoreos of the Chaco Boreal. J. Ethnopharmacol. 1993, 39, 105-111. [CrossRef]

2. Arenas, P. Etnobotánica Lengua-Maskoy; Fundación para la Educación, la Ciencia y la Cultura: Buenos Aires, Argentina, 1981; p. 149.

3. Alvarez, J.M.; Lopes, R.C.; Bortolotto, I.M. The ethnobotany of Herreria montevidensis Klotzsch ex Griseb.-Herreriaceae, in Corumbá, Brazil. Econ. Bot. 2008, 62, 187-191. [CrossRef]

4. Correia, P. Dicionário das Plantas úteis do Brasil; Ministerio da Agricultura e Instituto Brasileiro de Desenvolvimento Forestal: Rio de Janeiro, Brazil, 1984; Volume IV, p. 436, Volume VI, p. 21.

5. Hegnauer, R. Chemotaxonomie der Pflanzen; Birkhäuser Verlag: Basel, Switzerland, 1963; Volume 2. 
6. Cecy, C.; Yassumoto, Y. Steroidal saponins in the roots of Herreria montevidensis (Liliaceae). Trib. Farm. 1973, 40, 52-55.

7. Camarda, L.; Merlini, L.; Nasini, G. Dragon's blood from Dracaena draco, structure of novel homoisoflavonoids. Heterocycles 1983, 20, 39-43.

8. Masaoud, M.; Ripperger, H.; Porzel, A.; Adam, G. Flavonoids of Dragon's Blood from Dracaena cinnabari. Phytochemistry 1995, 38, 745-749. [CrossRef]

9. Luo, Y.; Wang, H.; Xu, X.; Mei, W.; Dai, H. Antioxidant phenolic compounds of Dracaena cambodiana. Molecules 2010, 15, 8904-8914. [CrossRef] [PubMed]

10. González, G.A.; León, F.; Sánchez-Pinto, L.; Padrón, J.I.; Bermejo, J. Phenolic compounds of Dragon's Blood from Dracaena draco. J. Nat. Prod. 2000, 63, 1297-1299. [CrossRef] [PubMed]

11. Tinto, W.F.; Simmons-Boyce, J.L.; McLean, S.; Reynolds, W.F. Constituents of Agave americana and Agave barbadensis. Fitoterapia 2005, 76, 594-597. [CrossRef] [PubMed]

12. Awale, S.; Miyamoto, T.; Linn, T.Z.; Li, F.; Win, N.N.; Tezuka, Y.; Esumi, H.; Kadota, S. Cytotoxic constituents of Soymida febrifuga from Myanmar. J. Nat. Prod. 2009, 72, 1631-1636. [CrossRef] [PubMed]

13. Ali, A.A.; Makboul, M.A.; Attia, A.A.; Ali, D.T. Chromones and flavans from Pancratium maritimum. Phytochemistry 1990, 29, 625-627. [CrossRef]

14. Liu, J.; Dai, H.-F.; Wu, J.; Zeng, Y.-B.; Mei, W.-L. Flavanes from Dracaena cambodiana. Z. Naturforsch. 2008, 63B, 1407-1410.

15. Fernández, M.I.; Pedro, J.R.; Seoane, E. Two polyhydroxystilbenes from stems of Phoenix dactylifera. Phytochemistry 1983, 22, 2819-2821. [CrossRef]

16. Buckingham, J. Dictionary of Natural Products on DVD, Version 25:1; CRC Press, Taylor \& Francis Group: Boca Raton, FL, USA, 2016.

17. Zhu, Y.; Zhang, P.; Yu, H.; Li, J.; Wang, M.-W.; Zhao, W. Anti-Helicobacter pylori and thrombin inhibitory components from Chinese Dragon's Blood, Dracaena cochinchinensis. J. Nat. Prod. 2007, 70, 1570-1577. [CrossRef] [PubMed]

18. Dewick, P.M. Biosynthesis of the 3-benzylchroman-4-one eucomin in Eucomis bicolor. Phytochemistry 1975, 14, 983-988. [CrossRef]

19. Agrawal, P.K.; Jain, D.C.; Gupta, R.K.; Thakur, R.S. Carbon-13 NMR spectroscopy of steroidal sapogenins and steroidal saponins. Phytochemistry 1985, 24, 2479-2496. [CrossRef]

20. Brandão, M.G.L.; Zanetti, N.N.S.; Oliveira, P.; Grael, C.F.F.; Santos, A.C.P.; Monte-Mór, R.L.M. Brazilian medicinal plants described by 19th century European naturalists and in the Official Pharmacopoeia. J. Ethnopharmacol. 2008, 120, 141-148. [CrossRef] [PubMed]

21. Pereira, F.L.; Oliveira, V.B.; Viana, C.T.R.; Campos, P.P.; Silva, M.A.N.; Brandão, M.G.L. Antihyperlipidemic and antihyperglycemic effects of the Brazilian salsaparrilhas Smilax brasiliensis Spreng. (Smilacaceae) and Herreria salsaparrilha Mart. (Agavaceae) in mice treated with a high-refined-carbohydrate containing diet. Food Res. Int. 2015, 76, 366-372. [CrossRef]

22. Jeon, S.-Y.; Kwon, S.-H.; Seong, Y.-H.; Bae, K.; Hur, J.-M.; Lee, Y.-Y.; Suh, D.-Y.; Song, K.-S. $\beta$-Secretase (BACE1)-inhibiting stilbenoids from Smilax Rhizoma. Phytomedicine 2007, 14, 403-408. [CrossRef] [PubMed]

23. Wang, W.-X.; Li, T.-X.; Ma, H.; Zhang, J.-F.; Jia, A.-Q. Tumoral cytotoxic and antioxidative phenylpropanoid glycosides in Smilax riparia A. DC. J. Ethnopharmacol. 2013, 149, 527-532. [CrossRef] [PubMed]

24. Wungsintaweekul, B.; Umehara, K.; Miyase, T.; Noguchi, H. Estrogenic and anti-estrogenic compounds from the Thai medicinal plant, Smilax corbularia (Smilacaceae). Phytochemistry 2011, 72, 495-502. [CrossRef] [PubMed]

25. Wang, Y.; Li, C.; Xiang, L.; Huang, W.; He, X. Spirostane saponins from Chinese onion (Allium chinense) exert pronounced anti-inflammatory and anti-proliferative activities. J. Funct. Foods 2016, 25, 208-219. [CrossRef]

Sample Availability: Samples of the compounds are not available from the authors. 